\title{
$\mathrm{GC}-\mathrm{ECD}$ 를 이용한 서울시 도시하천 퇴적물 중 $\mathrm{PCBs}$ 의 정량과 비용효과적인 Dioxin-like PCBs의 추정
}

\author{
이제승 ${ }^{\dagger} \cdot$ 조석주 · 길혜경 · 이목영
}

서울특별시보건환경연구원 물환경연구부

\section{Quantification of PCBs using GC-ECD and Cost-effective Estimation of Dioxin-like PCBs in the Sediment of Urban Streams in Seoul, Korea}

\author{
Je-Seung Lee ${ }^{\dagger}$, Suk-Joo Cho, Hye-Gyeong Gil, and Mok-Young Lee \\ Division of Water Environmental Research, Seoul Metropolitan Government Research Institute of Public Health and \\ Environment(SIHE), Gyeonggi-do, 13818, Korea
}

Received July 31, 2020 / Revised August 25, 2020 / Accepted September 14, 2020

\begin{abstract}
In this study, the concentration of polychlorinated biphenyls (PCBs) remaining in the sediment of Han River and its 4 tributaries was investigated in a cost-effective method using gas chromatography-electron capture detector (GC-ECD). The concentration of total PCBs was calculated by summing up the individual Aroclor concentration quantified using specific congeners of each Aroclor. By quantifying individual Aroclors, the concentration of dioxin-like PCBs (dl-PCBs) and toxicity equivalency quotient (TEQ) for sediment samples could be estimated using simple formulae derived from the information of dl-PCBs content in individual Aroclors. Although it was not possible to compare the estimated concentration of dl-PCBs with the concentration analyzed by high-resolution mass spectrometry (HRMS) for the same sample, acceptable results were obtained through comparison with the concentration of sediment samples at adjacent points in previous studies. As a result, PCB concentration remaining in the sediments in the urban stream was relatively high in the sediments near the industrial area. In the case of the two tributaries adjacent to the industrial area, the concentrations of PCBs in most sediment samples exceeded the effective range low (ERL) value and at certain points exceeded the effective range median (ERM) value. In addition, most high concentrations of PCBs were commonly detected at the junction of the river and its tributary where the flow rate slowed noticeably. Therefore, it is necessary to consider the junction of rivers as an important sampling point when investigating PCBs in sediments.
\end{abstract}

Key words: PCBs, Aroclor, GC-ECD, dl-PCBs, Sediment, SQGs

\section{1. 서 론}

폴리클로리네이티드비페닐(polychlorinated biphenyls, 이하 PCBs)은 1929년 미국에서 생산되기 시작하여 Aroclor, Kaneclor 등의 명칭으로 사용되어온 물질로 1930년부터 1970년대에 걸쳐 전 세계적으로 130만톤이 생산되었다.1) 이 물질은 잔류성 유기오염물질(persistent organic pollutants, 이하 POPs)로서 환경 중에 배출되 면 분해되지 않고 상당기간 동안 환경 중에 잔류하여 생태계 및 인간의 건강에 악영향을 미치게 된다. ${ }^{2)}$ 특히
PCBs는 발암성과 함께 내분비계장애물질로 알려져 있 어 지속적으로 관심의 대상이 되고 있다. 이러한 독성 으로 인해 미국 환경청(EPA)은 1979년에 PCBs의 사 용을 금지하는 조치를 취하였고, ${ }^{3,4)}$ 우리나라에서는 1996년 유해화학물질관리법에 의해 제조, 수입 그리고, 판매와 사용을 전면적으로 금지하게 되었다.)

그러나 $\mathrm{PCBs}$ 는 변압기, 축전기의 절연유, 윤활유, 가 소제, 도료 등 다양한 용도로 광범위하게 사용되었고 분해가 어려워 현재까지도 환경 중에 잔류할 가능성이 매우 큰 물질이라고 할 수 있다. ${ }^{6)}$ 또한 환경 중에 배

\footnotetext{
${ }^{\dagger}$ To whom correspondence should be addressed.
}

Tel: 82-2-570-3381, Fax: 82-2-570-3351, E-mail: infoban@seoul.go.kr 
출된 $\mathrm{PCBs}$ 는 다른 $\mathrm{POPs}$ 물질과 마찬가지로 최종적으 로 수계 퇴적물에 흡착되어 잔류하게 되므로 ${ }^{7-9)}$ 퇴적물 은 저서 생물에 있어 중요한 $\mathrm{PCBs}$ 노출경로가 된다. ${ }^{10)}$ 따라서 $\mathrm{PCBs}$ 의 최종적인 수용매체로서 퇴적물에 대한 조사가 필요하다고 하겠다.

한편 $\mathrm{PCBs}$ 조사를 위한 분석은 고분해능 질량분석기 (high resolution mass spectrometry, 이하 HRMS)를 이용 해서 동족체를 분석하는 방법과 $\mathrm{GC}-\mathrm{ECD}$ 의 크로마토그 램 패턴을 이용하여 $\mathrm{PCBs}$ 를 확인하고 패턴에 해당하는 Aroclor 등 PCBs 제품을 표준물질로 이용하여 총 PCBs 로 정량하는 방법이 있다. 전자의 경우는 개별 동족체의 농도를 알 수 있지만 분석비용이 상당히 고가인 관계로 분석 상의 접근이 쉽지 않은 단점이 있다. 반면 후자의 경우 개별 동족체의 농도에 관한 정보는 알 수 없지만 잔류하는 PCBs 제품(Aroclor)의 종류를 알 수 있고 분석 비용이 저렴한 장점이 있다. ${ }^{3)}$ 따라서 두 분석방법 간의 장단점을 파악하고 조사의 필요성과 목적에 따라 분석방 법을 선택함으로써 효과적으로 $\mathrm{PCBs}$ 를 조사할 수 있다.

본 연구에서는 서울시 하천 퇴적물에 존재하는 $\mathrm{PCBs}$ 를 $\mathrm{GC}-\mathrm{ECD}$ 를 이용해서 분석하였고, 선행논문 ${ }^{11)}$ 에서 제시된 PCBs 제품군(Aroclor)에 포함된 다이옥신 유사 $\mathrm{PCBs}$ (dioxin-like PCBs, 이하 dl-PCBs)의 함량정보를 이용하여 HRMS를 이용하지 않고 경제적으로 $\mathrm{dl}-\mathrm{PCBs}$ 와 독성등가치(toxicity equivalent, 이하 TEQ)를 추정 하였다. 이러한 방법은 총 $\mathrm{PCBs}$ 를 정량함으로써 미국 이나 캐나다에서 제시되는 퇴적물관리기준(sediment quality guidelines, 이하 SQGs)과의 비교를 용이하게 할 수 있고, 하천 퇴적물에 잔류하는 $\mathrm{PCBs}$ 의 조사를 상대 적으로 쉬운 분석방법과 저비용으로 할 수 있어 오염 관리자들에게 더 많은 오염우려지역에 대한 조사를 가 능하도록 할 수 있다. 이를 통해 하천 퇴적물 우선 관 리지역 선정과 정밀조사가 필요한 지역에 대한 참고자 료를 제공할 수 있을 것이다.

\section{2. 재료 및 방법}

\section{1. 시료}

퇴적물 시료채취는 한강이 서울시를 통과하는 구간 에서 한강본류 및 4개의 주요 지천을 대상으로 2018년 6 월에서 11 월간에 걸쳐 이루어졌다. 4 개의 지천은 한강 (H-river)의 상류에서 하류방향으로 탄천(T-stream), 중랑 천(J-stream), 홍제천(H-stream) 그리고 안양천(A-stream)이 위치하고 있다(Fig. 1).
지천 시료는 홍제천 구간 $\mathrm{H} 1 \sim \mathrm{H} 3$, 안양천 구간 $\mathrm{A} 1 \sim \mathrm{A} 3$, 탄천 구간 $\mathrm{T} 1 \sim \mathrm{T} 3$ 그리고 중랑천 구간 $\mathrm{J} 1 \sim \mathrm{J} 3$ 에 서 채취하였다. 한강 본류의 시료는 대부분 중랑천(J)과 안양천(A)의 한강 합류부 인근의 흐름방향 하류(JH site, $\mathrm{AH}$ site)에서 채취한 것으로 중랑천 합류 이후의 $\mathrm{JH} 1$ 지점 JH6 지점, 안양천 합류 이후 시료인 $\mathrm{AH} 1$ 지점 $\sim \mathrm{AH} 8$ 지점, 탄천 합류 이후의 $\mathrm{TH} 1$ 지점이었다. 그리고 한강의 서울시 구간 상류 측 2 개 지점(HR1, HR2) 과 중하류측 1 개 지점(HR3)에서 배경지점 시료를 채취하였 다. 전체 시료채취 지점은 30 개 지점이었다.

시료채취는 잠수부에 의해 수중에서 코어채취기(Core sampler)를 이용해서 채취하였다. Table 1은 본 연구에서 채취한 시료의 특징을 보여주고 있다. 채취한 퇴적물의 두께는 $8 \mathrm{~cm} \sim 53 \mathrm{~cm}$ 이었고, 일부를 제외하고는 두 층으 로 나누어 분취하였다. 퇴적물의 분취는 일정한 깊이로 구분한 것은 아니고, 모래질, 실트질 등 퇴적물 조직에 따라 구분하여 채취하였다. 전체적으로 시료는 회색과 갈 색계열의 색을 띠고 있었으며, 지점별 시료는 퇴적물의 조직에 따라 층별로 색상의 차이를 구분할 수 있었다. 또한, 대부분의 시료에서 황의 취기를 확인할 수 있었다.

\section{2. 전처리 및 기기분석}

채취한 시료는 잘 혼합한 후 약 $500 \mathrm{~g}$ 을 취하여 오 븐에서 $40^{\circ} \mathrm{C}$ 로 48 시간 동안 건조하였고, 그 후 1 주일 간 더 자연 건조하였다. 건조된 시료는 적당량을 분취 한 후 마노(agate) 재질의 유발과 $0.1 \mathrm{~mm}$ 체 $(150 \mathrm{mesh})$ 를 이용해서 분취한 시료의 약 $80 \%$ 가 체를 통과하도 록 분쇄와 체질을 반복하여 분석용 시료를 제조하였다.

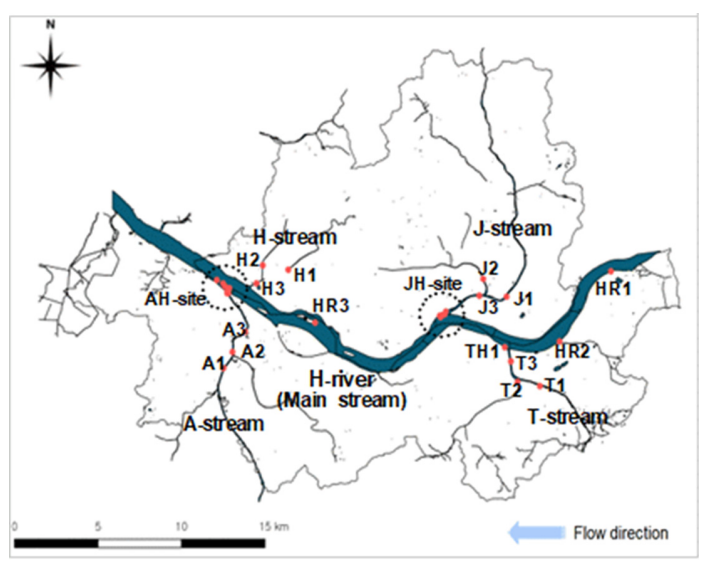

Fig. 1. Sampling points. The coordinate ranges of sampling points are $\mathrm{X}(126.86878$ - 127.13661) and $\mathrm{Y}(37.49795$ - 37.57108). 
Table 1. Information on sediment samples at each sampling point

\begin{tabular}{|c|c|c|c|c|c|c|c|}
\hline \multirow{2}{*}{$\begin{array}{l}\text { Point } \\
\text { No. }\end{array}$} & \multirow{2}{*}{ Sample No. } & \multirow{2}{*}{ Longitude } & \multirow{2}{*}{ Latitude } & \multirow{2}{*}{$\begin{array}{c}\text { Odor } \\
\text { (Surfur) }\end{array}$} & \multirow{2}{*}{ Soil texture } & \multicolumn{2}{|c|}{ Layer(Cm) } \\
\hline & & & & & & Segment & Total \\
\hline J1 & $\mathrm{J} 1-1 / \mathrm{J} 1-2$ & $127-03-56.56$ & $37-33-07.61$ & 0 & silty/sandy & $24 / 17$ & 41 \\
\hline $\mathrm{J} 2$ & $\mathrm{~J} 2-1 / \mathrm{J} 2-2$ & $127-02-59.52$ & $37-33-46.24$ & 0 & silty/sandy & $20 / 13$ & 33 \\
\hline $\mathrm{J} 3$ & $\mathrm{~J} 3-1 / \mathrm{J} 3-2$ & $127-02-49.99$ & $37-33-09.69$ & 0 & silty/sandy & $6 / 25$ & 31 \\
\hline JH1 & JH1-1/JH1-2 & $127-01-28.80$ & $37-32-35.30$ & 0 & sandy/silty & $11 / 20$ & 31 \\
\hline $\mathrm{JH} 2$ & JH2-1/JH2-2 & $127-01-25.40$ & $37-32-29.40$ & 0 & silty/mudy & $10 / 38$ & 48 \\
\hline JH3 & JH3-1/JH3-2 & $127-01-18.50$ & $37-32-27.90$ & O & silty/sandy & $24 / 17$ & 41 \\
\hline JH4 & JH4-1 & $127-01-13.00$ & $37-32-26.10$ & 0 & silty/sandy & 38 & 38 \\
\hline JH5 & JH5-1/JH5-2 & $127-01-15.60$ & $37-32-23.70$ & 0 & silty/sandy & $23 / 9$ & 32 \\
\hline JH6 & JH6-1/JH6-2 & $127-01-14.50$ & $37-32-26.90$ & 0 & silty/sandy & $17 / 22$ & 39 \\
\hline A1 & A1-1/A1-2 & $126-52-24.07$ & $37-30-31.97$ & $\times$ & silty/sandy & $10 / 16$ & 26 \\
\hline A2 & A2-1/A2-2 & $126-52-45.83$ & $37-31-06.85$ & O & silty/sandy & $9 / 13$ & 22 \\
\hline A3 & A3-1 & $126-53-16.92$ & $37-31-51.36$ & 0 & sandy & 14 & 14 \\
\hline AH1 & AH1-1 & $126-52-35.77$ & $37-33-15.20$ & 0 & sandy & 18 & 18 \\
\hline $\mathrm{AH} 2$ & AH2-1 & $126-52-36.70$ & $37-33-16.20$ & 0 & sandy & 19 & 19 \\
\hline $\mathrm{AH} 3$ & АH3-1/AH3-2 & $126-52-33.30$ & $37-33-15.70$ & $x$ & silty/mudy & $31 / 22$ & 53 \\
\hline AH4 & AH4-1/AH4-2 & $126-52-32.62$ & $37-33-17.68$ & 0 & silty/mudy & $20 / 24$ & 44 \\
\hline AH5 & AH5-1/AH5-2 & $126-52-38.15$ & $37-33-26.20$ & 0 & silty/mudy & $22 / 14$ & 36 \\
\hline AH6 & AH6-1/AH6-2 & $126-52-27.16$ & $37-33-30.28$ & 0 & silty/mudy & $35 / 15$ & 50 \\
\hline AH7 & AH7-1/AH7-2 & $126-52-22.74$ & $37-33-36.45$ & 0 & mudy & $9 / 43$ & 52 \\
\hline AH8 & AH8-1/AH8-2 & $126-52-07.59$ & $37-33-43.83$ & $x$ & silty/mudy & $16 / 34$ & 50 \\
\hline $\mathrm{T} 1$ & $\mathrm{~T} 1-1 / \mathrm{T} 1-2$ & $127-05-18.16$ & $37-29-52.63$ & 0 & sandy & $9 / 25$ & 34 \\
\hline $\mathrm{T} 2$ & $\mathrm{~T} 2-1 / \mathrm{T} 2-2$ & $127-04-23.37$ & $37-30-01.70$ & $x$ & sandy/silty & $36 / 13$ & 39 \\
\hline $\mathrm{T} 3$ & T3-1/T3-2 & $127-04-07.16$ & $37-30-46.58$ & 0 & sandy/silty & $7 / 28$ & 35 \\
\hline TH1 & TH1-1/TH1-2 & $127-03-52.18$ & $37-31-17.40$ & 0 & silty/sandy & $21 / 14$ & 35 \\
\hline $\mathrm{H} 1$ & H1-1 & $126-55-02.44$ & $37-34-06.30$ & 0 & sandy & 8 & 8 \\
\hline $\mathrm{H} 2$ & $\mathrm{H} 2-1 / \mathrm{H} 2-2$ & $126-53-59.91$ & $37-34-15.90$ & 0 & sandy & $7 / 13$ & 20 \\
\hline $\mathrm{H} 3$ & $\mathrm{H} 3-1 / \mathrm{H} 3-2$ & $126-53-44.57$ & $37-33-36.69$ & O & gravel & $13 / 14$ & 27 \\
\hline HR1 & HR1 & $127-08-11.80$ & $37-34-02.86$ & $x$ & silty & 19 & 19 \\
\hline HR2 & HR2 & $127-06-06.32$ & $37-31-29.67$ & $x$ & sandy & 20 & 20 \\
\hline HR3 & HR3 & $126-56-08.90$ & $37-32-11.30$ & 0 & sandy & 28 & 28 \\
\hline
\end{tabular}

시료 중 $\mathrm{PCBs}$ 의 추출은 가압용매추출(Pressured fluid extraction) 방법을 이용하였고, 사용된 추출장비는 ASE 350(Thermo Fisher Scientific, Sunnyvale, CA, $\mathrm{USA})$ 이었다. 분석시료는 $10 \mathrm{~g}$ 을 정확히 취하여 추출 셀 에 넣었고, 이 때 회수율 보정을 위해 대체 표준물질 (surrogate standard)로 PCB-209(Accustandard, New Haven, CT, USA)를 $100 \mathrm{ng}$ 을 취하여 셀에 주입하였다. 가압용매추출을 위한 장치의 운전조건은 추출온도 $150^{\circ} \mathrm{C}$, 추출압력 $1500 \mathrm{psi}$, 그리고 유지시간(static time) 5 분으로 설정하였고, 이 조건에서 1 회 $(1 \mathrm{cycle})$ 추출하였 다. 추출용매는 헥산(Hexane300, Wako, Osaka, Japan) 을 사용하였다.

추출한 용액는 무수황산나트륨으로 수분을 제거하고 질소가스를 이용하여 약 $1 \mathrm{~mL}$ 로 농축 후 시판되는 실리
카겔 카트리지 컬럼(SI-1 Silica, $1 \mathrm{~g} / 6 \mathrm{~mL}$, Phenomenex, Torrance, CA, USA)으로 정제를 실시하였다. 이 때 퇴적 물에 흔히 존재하는 황 성분에 의해 발생할 수 있는 정 량 상의 방해를 제거하기 위해 농축시료를 활성화된 입 상 구리(40 80 mesh, Wako, Osaka, Japan)가 적당량 첨 가된 실리카겔 카트리지 컬럼 상부로 옮기고 반응을 위 해 5 분간 정치한 후 정제를 시작하였다. 정제한 용액은 $1 \mathrm{~mL}$ 로 농축 후 기기분석을 실시하였다. 그 후 기기분 석에서 나타난 $\mathrm{GC}$ 크로마토그램을 확인하고 필요한 경 우 시료를 황산처리 후 상기의 정제를 다시 수행하였다.

분석기기는 GC-ECD(GC-2010plus, Shimadzu, Kyoto, Japan)를 이용하였고, 사용한 컬럼은 SH-Rxi-5ms $(0.32 \mathrm{~mm}$ i.d. $\times 0.25 \mu \mathrm{m}$ thickness $\times 30 \mathrm{~m}$ length, Shimadzu, Kyoto, Japan)이었다. GC분석 온도조건은 운반가스로서 헬륨 
(He)을 분당 $1 \mathrm{~mL}$ 의 유량으로 흘려주면서 $100^{\circ} \mathrm{C}$ 에서 $160^{\circ} \mathrm{C}$ 까지 분당 $15^{\circ} \mathrm{C}$ 로 승온한 후 다시 분당 $5^{\circ} \mathrm{C}$ 로 $300^{\circ} \mathrm{C}$ 까지 승온하였다.

\section{3. 개별 Aroclor 정량}

우리나라 공정시험기준에서는 소각 등 비의도적으로 배출된 $\mathrm{PCBs}$ 를 제외하고 PCBs 제품의 사용으로 인한 토양, 폐기물 및 물 등의 환경매체 중에 존재하는 PCBs를 Aroclor 표준물질(Accustandard, New Haven, $\mathrm{CT}, \mathrm{USA})$ 을 이용해서 $\mathrm{GC}-\mathrm{ECD}$ 로 총 $\mathrm{PCBs}$ 를 정량하 고 있다. ${ }^{12-14)}$ 이 방법은 시료에서 검출되는 $\mathrm{PCBs}$ 의 크 로마토그램 피크패턴과 Aroclor1242, Aroclor1254, Aroclor 1260 의 패턴의 일치성으로 정성분석을 하고, 단 일 PCBs 제품에 의한 오염인 경우 해당 Aroclor 표준 물질로 표준용액을 제조하고, 2가지 이상의 Aroclor에 의한 혼합오염의 경우는 혼합된 각 Aroclor제품의 혼합 비를 정수비로 구한 후 계산된 혼합비에 맞게 표준용 액을 제조하여 정량에 이용하게 된다. 이들 방법에서는 개별 Aroclor를 정량하는 것이 아닌 총 $\mathrm{PCBs}$ 를 정량 하게 되는데, 시료에 따라 표준물질을 달리해야 하므로 $\mathrm{PCBs}$ 로 오염된 지역을 조사하는 경우와 같이 PCBs가 검출되는 시료가 많을 경우에는 표준물질 제조가 복합 하게 되거나 불가능하게 된다. 또한 혼합비를 정수화하 는 과정에서 큰 오차가 발생할 가능성이 있다. 본 연구 에서는 이러한 분석 상의 문제점을 해결하기 위해 개 별 Aroclor에 고유하거나 상대적으로 고비율로 존재하 는 특성 피크들을 이용해서 개별 Aroclor를 분석하였고, 이들 개별 Aroclor의 농도를 합하여 총 $\mathrm{PCBs}$ 를 계산 하였다. 이렇게 함으로써 서로 다른 혼합비를 가진 시 료가 많을 경우에도 비교적 용이하게 $\mathrm{PCBs}$ 를 정량할 수 있고, 개별 Aroclor 농도에 대한 정보도 획득할 수 있게 된다. 이러한 PCBs 동족체의 IUPAC No.는 Aroclor 1242 의 경우 PCB-5, $8,15,16,17,18,20,22,28,31,32$, 33,53 이 있고, Aroclor1254는 PCB-77, 86, 97, 99, 110, 154, Aroclor1260은 PCB-194, 195, 196, 199, 203, 206, 208 등이 있다. 이들 Aroclor별 특이 동족체 들 중에서 피크의 크기, 시료 중 방해 피크의 유무 등을 고려하여 적절한 동족체를 선정하여 정량에 이용하였다. 본 연구에서 정량에 이용한 동족체는 Table 2 와 같다.

Table 3는 동일한 양의 Aroclor 혼합표준물질에서 분 리된 각 동족체들의 면적을 보여주고 있다. 표에서 보 듯이 Aroclor1254는 고유한 동족체가 없으며 상대적으 로 고비율로 존재하는 동족체가 존재하지만 이들 동족
Table 2. PCB congeners selected to quantify each Aroclor

\begin{tabular}{cc}
\hline \hline Aroclor species & IUPAC No. of PCB congeners \\
\hline Aroclor1242 & PCB-15, 16, 17, 18, 28, 31, 32 \\
Aroclor1254 & PCB-77, 86, 97, 99, 110, 154 \\
Aroclor1260 & PCB-196, 199, 203 \\
\hline
\end{tabular}

체도 상당한 정도로 Aroclor1242의 동족체를 포함하고 있다. 따라서 Aroclor 제품이 혼합된 오염 시료의 경우 이들 중첩된 피크들을 보정하지 않으면 Aroclor1254의 농도가 과대 정량될 우려가 있다. 따라서 이러한 정량상 의 문제를 합리적으로 해결하기 위해 Aroclor 1254 의 정 량에 이용되는 동족체들로 Aroclor1242의 검정곡선식을 산정하고, 시료 중의 Aroclor1242의 농도에 해당하는 면 적을 계산한 후 시료에서 검출된 Aroclor1254 정량 동 족체의 면적에서 Aroclor1242에서 유래한 면적을 차감 하는 방식으로 보정을 수행하였다. 같은 방법으로 Aroclor1260과 공통적인 Aroclor1254 정량피크의 보정도 가능하지만, Aroclor1254의 정량에 미치는 영향이 미미 하고 실제 본 연구에서의 퇴적물 시료 중의 Aroclor 1260 의 농도가 미량이므로 이 부분은 보정하지 않았다.

\subsection{Dioxin-like PCBs의 추정}

Table 4는 선행연구에 ${ }^{11)}$ 서 보고된 개별 Aroclor에 함 유된 dl-PCBs의 농도와 $\mathrm{TEQ}$ 를 보여주고 있는데, 만약 퇴적물과 같은 환경시료에서 개별 Aroclor의 농도를 정 량 할 수 있으면 이들 정보를 이용해서 시료 중 $\mathrm{dl}-$ $\mathrm{PCBs}$ 농도와 $\mathrm{TEQ}$ 의 추정이 가능할 수 있다.

본 연구에서는 $\mathrm{GC}-\mathrm{ECD}$ 를 이용하여 정량한 개별 Aroclor 농도를 이용하여 dl-PCBs 농도와 $\mathrm{TEQ}$ 로 환산 하기 위해 아래의 Eq.1 및 Eq.2와 같은 간단한 식을 유도하였다. 아래 식에서 $\mathrm{C}_{1242}, \mathrm{C}_{1254}$ 및 $\mathrm{C}_{1260}$ 은 각각 $\mathrm{GC}-\mathrm{ECD}$ 로 정량한 퇴적물 시료 중의 Aroclor1242, Aroclor1254 및 Aroclor1260의 농도 $(\mu \mathrm{g} / \mathrm{kg})$ 를 나타내고 있다. 이러한 방법은 HRMS를 이용하지 않고도 비용효 과적인 방법으로 $\mathrm{dl}-\mathrm{PCBs}$ 와 $\mathrm{TEQ}$ 를 추정할 수 있는 장점이 있다.

$$
\begin{aligned}
& \text { dl-PCBs }(\mu \mathrm{g} / \mathrm{kg})= \\
& \left(15.731 \times \mathrm{C}_{1242}+129.665 \times \mathrm{C}_{1254}+14.498 \times \mathrm{C}_{1260}\right) \times 10^{-3}
\end{aligned}
$$

TEQ (ng TEQ $/ \mathrm{kg})=$

$$
\left(4.06 \times \mathrm{C}_{1242}+7.66 \times \mathrm{C}_{1254}+0.65 \times \mathrm{C}_{1260}\right) \times 10^{-3}
$$


Table 3. PCB congeners included in each Aroclor (mass of each Aroclor is $0.35 \mathrm{ng}$ )

\begin{tabular}{|c|c|c|c|c|c|c|c|c|c|}
\hline \multirow{2}{*}{$\begin{array}{l}\text { IUPAC No. of } \\
\text { PCB congeners }\end{array}$} & \multirow{2}{*}{ RT } & \multicolumn{2}{|c|}{ Aroclor1242 } & \multicolumn{2}{|c|}{ Aroclor 1254} & \multicolumn{2}{|c|}{ Aroclor 1260} & \multicolumn{2}{|c|}{$\sum$ Aroclors } \\
\hline & & Area & Area \% & Area & Area \% & Area & Area $\%$ & Area & Area \% \\
\hline $8 / 5$ & 19.766 & 34658 & 100.0 & 0 & 0.0 & 0 & 0.0 & 34658 & 100 \\
\hline 18 & 21.634 & 45417 & 100.0 & 0 & 0.0 & 0 & 0.0 & 45417 & 100 \\
\hline $17 / 15$ & 21.741 & 29659 & 79.1 & 4113 & 11.0 & 3700 & 9.9 & 37472 & 100 \\
\hline $16 / 32$ & 22.518 & 36782 & 100.0 & 0 & 0.0 & 0 & 0.0 & 36782 & 100 \\
\hline 31 & 23.655 & 50242 & 96.9 & 1581 & 3.1 & 0 & 0.0 & 51823 & 100 \\
\hline 28 & 23.735 & 58232 & 98.0 & 1177 & 2.0 & 0 & 0.0 & 59409 & 100 \\
\hline $20 / 33 / 53$ & 24.188 & 47907 & 96.2 & 1900 & 3.8 & 0 & 0.0 & 49807 & 100 \\
\hline 22 & 24.545 & 25157 & 100.0 & 0 & 0.0 & 0 & 0.0 & 25157 & 100 \\
\hline 52 & 25.265 & 40689 & 45.0 & 49765 & 55.0 & 0 & 0.0 & 90454 & 100 \\
\hline $43 / 49$ & 25.483 & 26648 & 71.4 & 10649 & 28.6 & 0 & 0.0 & 37297 & 100 \\
\hline 44 & 26.255 & 33975 & 60.2 & 22445 & 39.8 & 0 & 0.0 & 56420 & 100 \\
\hline $41 / 64$ & 26.842 & 29654 & 77.4 & 8653 & 22.6 & 0 & 0.0 & 38307 & 100 \\
\hline 74 & 27.877 & 22238 & 70.2 & 9420 & 29.8 & 0 & 0.0 & 31658 & 100 \\
\hline $70 / 72 / 102$ & 28.032 & 38930 & 52.7 & 34899 & 47.3 & 0 & 0.0 & 73829 & 100 \\
\hline $66 / 95$ & 28.256 & 44412 & 29.9 & 73130 & 49.2 & 31003 & 20.9 & 148545 & 100 \\
\hline 91 & 28.565 & 5505 & 26.4 & 13383 & 64.1 & 1983 & 9.5 & 20871 & 100 \\
\hline $56 / 60 / 92$ & 29.013 & 35423 & 54.9 & 23325 & 36.1 & 5792 & 9.0 & 64540 & 100 \\
\hline $84 / 101 / 90 / 89$ & 29.27 & 16908 & 10.6 & 100637 & 63.4 & 41249 & 26.0 & 158794 & 100 \\
\hline 99 & 29.528 & 7251 & 17.3 & 34611 & 82.7 & 0 & 0.0 & 41862 & 100 \\
\hline 83 & 30.058 & 1072 & 16.0 & 5615 & 84.0 & 0 & 0.0 & 6687 & 100 \\
\hline $97 / 86$ & 30.301 & 5982 & 15.8 & 30500 & 80.4 & 1465 & 3.9 & 37947 & 100 \\
\hline $115 / 117 / 81 / 87$ & 30.533 & 9871 & 13.5 & 54911 & 75.0 & 8471 & 11.6 & 73253 & 100 \\
\hline $154 / 77 / 110$ & 30.995 & 15706 & 11.5 & 100551 & 73.8 & 19908 & 14.6 & 136165 & 100 \\
\hline $82 / 151$ & 31.546 & 4134 & 6.2 & 21696 & 32.4 & 41169 & 61.4 & 66999 & 100 \\
\hline $123 / 149 / 118 / 139$ & 32.103 & 0 & 0.0 & 0 & 0.0 & 95876 & 100.0 & 95876 & 100 \\
\hline $123 / 149 / 118 / 139$ & 32.103 & 12529 & 10.0 & 113256 & 90.0 & 0 & 0.0 & 125785 & 100 \\
\hline 153 & 33.157 & 1364 & 0.9 & 48250 & 31.9 & 101589 & 67.2 & 151203 & 100 \\
\hline $105 / 132$ & 33.382 & 9871 & 8.8 & 65276 & 58.1 & 37182 & 33.1 & 112329 & 100 \\
\hline 141 & 33.758 & 0 & 0.0 & 16309 & 29.1 & 39658 & 70.9 & 55967 & 100 \\
\hline $163 / 138 / 164$ & 34.455 & 2952 & 1.6 & 80927 & 42.8 & 105172 & 55.6 & 189051 & 100 \\
\hline $166 / 187$ & 35.199 & 0 & 0.0 & 4262 & 6.3 & 63149 & 93.7 & 67411 & 100 \\
\hline 183 & 35.43 & 0 & 0.0 & 3326 & 8.7 & 35067 & 91.3 & 38393 & 100 \\
\hline $167 / 128$ & 35.736 & 0 & 0.0 & 26690 & 68.9 & 12055 & 31.1 & 38745 & 100 \\
\hline $174 / 181$ & 36.28 & 0 & 0.0 & 5601 & 8.2 & 62405 & 91.8 & 68006 & 100 \\
\hline 177 & 36.538 & 0 & 0.0 & 3174 & 8.2 & 35594 & 91.8 & 38768 & 100 \\
\hline $156 / 171 / 202$ & 36.753 & 0 & 0.0 & 15628 & 33.8 & 30596 & 66.2 & 46224 & 100 \\
\hline 180 & 37.475 & 0 & 0.0 & 15201 & 11.1 & 122334 & 88.9 & 137535 & 100 \\
\hline 170 & 38.831 & 0 & 0.0 & 10401 & 12.7 & 71498 & 87.3 & 81899 & 100 \\
\hline 199 & 39.189 & 0 & 0.0 & 0 & 0.0 & 31994 & 100.0 & 31994 & 100 \\
\hline $196 / 203$ & 39.434 & 0 & 0.0 & 0 & 0.0 & 36256 & 100.0 & 36256 & 100 \\
\hline $195 / 208$ & 40.796 & 0 & 0.0 & 0 & 0.0 & 18277 & 100.0 & 18277 & 100 \\
\hline 194 & 41.602 & 0 & 0.0 & 0 & 0.0 & 40525 & 100.0 & 40525 & 100 \\
\hline 206 & 43.401 & 0 & 0.0 & 0 & 0.0 & 20550 & 100.0 & 20550 & 100 \\
\hline
\end{tabular}

(Note) Gray shaded lines represent selected PCB congeners to quantify each Aroclor and dark gray shaded part shows the commonly included congeners in Aroclor1242 and Aroclor1254

\section{5. $\mathrm{QA} / \mathrm{QC}$}

개별 Aroclor의 검정곡선의 직선성은 각 Aroclor별로 선정된 정량 동족체들에 대해서 $\mathrm{r}^{2}$ 값이 0.995 이상으로
양호하게 나타났다. 방법검출한계(MDL)와 정확도 (Accuracy, \%) 및 정밀도(Precision, \%)는 시판 바다모래 (Sea sand, Fisher scientific Inc.)에 각 Aroclor 표준물질 
Table 4. Concentrations $(\mu \mathrm{g} / \mathrm{g})$ of dl-PCBs in three Aroclors and total TEQ ( $\mu \mathrm{g}$ TEQ/g)

\begin{tabular}{lccccc}
\hline \multicolumn{1}{c}{ Congener } & IUPAC No. & WHO TEF (2005) & Aroclor 1242 & Aroclor 1254 & Aroclor 1260 \\
\hline $3,3^{\prime}, 4,4^{\prime}-\mathrm{TeCB}$ & 77 & 0.0001 & 2,590 & 174 & 33.8 \\
$3,4,4^{\prime}, 5-\mathrm{TeCB}$ & 81 & 0.0003 & 156 & 16.4 & 3.33 \\
$2,3^{\prime}, 3^{\prime}, 4^{\prime} 4^{\prime}-\mathrm{PeCB}$ & 105 & 0.00003 & 4,840 & 33,800 & 434 \\
$2,3,4^{\prime}, 4^{\prime}, 5^{-}-\mathrm{PeCB}$ & 114 & 0.00003 & 443 & 1930 & 17.0 \\
$2,3^{\prime}, 4,4^{\prime}, 5-\mathrm{PeCB}$ & 118 & 0.00003 & 6,980 & 78,900 & 5,610 \\
$2^{\prime}, 3,4,4^{\prime}, 5-\mathrm{PeCB}$ & 123 & 0.00003 & 277 & 1150 & 5.02 \\
$3,3^{\prime}, 4,4^{\prime}, 5-\mathrm{PeCB}$ & 126 & 0.1 & 33.6 & 37.3 & 2.13 \\
$2,3^{\prime}, 3^{\prime}, 4^{\prime}, 4^{\prime}, 5-\mathrm{HxCB}$ & 156 & 0.00003 & 255 & 8,440 & 4,860 \\
$2,3^{\prime}, 4,4^{\prime}, 5^{\prime}-\mathrm{HxCB}$ & 157 & 0.00003 & 70.9 & 1,870 & 252 \\
$2,3^{\prime}, 4,4^{\prime}, 5,5^{\prime}-\mathrm{HxCB}$ & 167 & 0.00003 & 80.7 & 3,100 & 1,990 \\
$3,3^{\prime}, 4,4^{\prime}, 5,5^{\prime}-\mathrm{HxCB}$ & 169 & 0.03 & 0.11 & 0.81 & 0.82 \\
$2,3,3^{\prime}, 4,4^{\prime}, 5,5^{\prime}-\mathrm{HpCB}$ & 189 & 0.00003 & 4.53 & 246 & 1,290 \\
\hline$\sum \mathrm{dl}-\mathrm{PCBs}$ & & & $15,730.84$ & $129,664.5$ & $14,498.1$ \\
total TEQ & & & 4.06 & 7.66 & 0.65 \\
\hline
\end{tabular}

(Note) This table is partially modified from the table in Dale R et al.(2004) and Aroclor total TEQ was recalculated with WHO TEF(2005) of each PCB congener

을 첨가한 시료로 평가하였는데, 산출된 방법검출한계 $(\mathrm{n}=7$, s.d. $\times 3.14)$ 는 Aroclor1242 $6.3 \mu \mathrm{g} / \mathrm{kg}$, Aroclor 1254 $4.7 \mu \mathrm{g} / \mathrm{kg}$, Aroclor1260 $7.2 \mu \mathrm{g} / \mathrm{kg}$ 이었고, 정확도 $(\mathrm{n}=4)$ 는 $72 \% \sim 78 \%$, 정밀도 $(\mathrm{n}=4)$ 는 $0.5 \% \sim 1.5 \%$ 로 나타났다. 그리고 대체표준물질로 퇴적물 시료에 첨가한 PCB-209 의 회수율은 전체시료 $(\mathrm{n}=53)$ 에 대해서 $69 \% \sim 118 \%$ 의 범위로 나타났다.

Aroclor의 정량은 크로마토그램 피크의 패턴일치를 기본으로 한다. 따라서 정량한계 이상의 농도를 나타내 는 시료의 경우에도 피크패턴이 확인되지 않은 경우는 $\mathrm{PCBs}$ 가 검출되지 않는 것으로 하였다. 따라서 본 연구 에서 PCBs가 검출되지 않은 시료는 Aroclor 피크패턴 이 확인되지 않았음을 표현한 것으로, 도시폐기물 소각 등으로 환경시료 중에 존재할 수 있는 다양하고 미량 인 $\mathrm{PCBs}$ 동족체들에 대한 정보는 제공하지 못하는 것 을 밝혀둔다. 반대로 정량한계 미만으로 검출되었더라 도 피크패턴이 확인 가능한 경우에는 참고적으로 정량 분석을 수행하고 그 수치를 제시하였다.

\section{3. 결과 및 고찰}

\section{1. 지점별 $\mathrm{PCBs}$ 잔류농도 및 Aroclor의 종류}

Table 5는 전체 조사지점에서의 총 $\mathrm{PCBs}$ 농도와 세 종류의 Aroclor의 개별농도를 보여주고 있다. 총 $\mathrm{PCBs}$ 농도는 개별 Aroclor의 합으로 계산하였다. Table 5에 서 보는 바와 같이 조사지점 대부분의 퇴적물에서
Aroclor의 크로마토그램 피크 패턴을 확인할 수 있었지 만, $\mathrm{T} 1$ 지점과 $\mathrm{H} 3$ 지점에서는 피크 패턴을 확인할 수 없 었다. 전체 조사지점 중 $\mathrm{PCBs}$ 최고농도는 $\mathrm{JH} 1$ 지점으 로 $207.5 \mu \mathrm{g} / \mathrm{kg}$ 로 나타났다. 한강의 주요 4개 지천에서 의 $\mathrm{PCBs}$ 농도는 중랑천과 안양천의 퇴적물에서 상대 적으로 높게 나타나고 있었고, 탄천과 홍제천 퇴적물에 서는 대부분 정량한계 미만으로 검출되거나 정량한계 미만의 농도 수준에서 Aroclor의 흔적만 확인할 수 있 었다. 이러한 지천별 $\mathrm{PCBs}$ 의 잔류현황은 인위적인 오 염원 지역으로서 서울시의 준공업지역(이하 공업지역) 의 분포와 무관하지 않을 것으로 판단되는데, 공업지역 주변의 유역이나 호소 퇴적물에서 상대적으로 고농도 의 $\mathrm{PCBs}$ 가 검출되는 다양한 사례들이 세계 도처에서 보고되고 있다 ${ }^{15-17)}$. 서울시의 경우 1960 년대 산업화 시 기 이래 도시화와 공업화가 급속하게 이루어져 왔었고, 2005 년 기준 서울시 제조업의 $31.9 \%$ 가 공업지역 내에 밀집하여 산업활동을 수행하였다. ${ }^{18)}$ Fig. 2를 보면 서 울시의 주요 공업지역이 안양천 주변과 중랑천 주변에 위치하는 것을 볼 수 있다. 특히 안양천의 경우 상대적 으로 넓은 공업지역이 분포하고 있으며, 중랑천의 경우 에도 중랑천 수계 상류와 하류에 공업지역이 분포하고 있다. 또한 중랑천의 지천인 청계천의 퇴적물 $(\mathrm{J} 2)$ 에서도 $64.6 \mu \mathrm{g} / \mathrm{kg}$ d.w.의 PCBs가 검출되었는데 청계천 주변 에서도 과거 소규모 공장들이 밀집되어 운영되었던 특 징이 있다. 탄천과 홍제천 주변에는 공업지역이 존재하 지 않고 대부분 주거 및 상업지역으로 이루어져 있으 
Table 5. Concentrations of t-PCBs $(\mu \mathrm{g} / \mathrm{kg}$ d.w. $)$ at all sampling points in this study. The concentrations of three Aroclors were summed to calculate t-PCBs

\begin{tabular}{|c|c|c|c|c|c|}
\hline Sample No. & $\mathrm{t}-\mathrm{PCBs}$ & Aroclor1242 & Aroclor 1254 & Aroclor 1260 & $\begin{array}{c}\text { Aroclor ratio } \\
(1242: 1254: 1260)\end{array}$ \\
\hline $\bar{J} 1-1 / J 1-2$ & $9.4^{*} / 15.5$ & $5.6^{*} / 9.9$ & $3.9^{*} / 4.8$ & n.d./0.8 & $1.4: 1.0: 0.0 / 12.7: 6.2: 1.0$ \\
\hline $\mathrm{J} 2-1 / \mathrm{J} 2-2$ & $64.6 / 64.3$ & $29.1 / 33.3$ & $28.3 / 22.5$ & $7.2 / 8.5$ & $4.1: 3.9: 1.0 / 3.9: 2.6: 1.0$ \\
\hline J3-1/J3-2 & $35.3 / 3.6$ & $14.6 / 2.7$ & $11.3 / 1.0$ & 9.4/n.d. & $1.6: 1.2: 1.0 / 2.8: 1.0: 0.0$ \\
\hline JH1-1/JH1-2 & $62.7 / 207.5$ & $57.7 / 128.2$ & $1.4 / 43.6$ & $3.6 / 35.7$ & $16.0: 0.4: 1.0 / 3.6: 1.2: 1.0$ \\
\hline $\mathrm{JH} 2-1 / \mathrm{JH} 2-2$ & $43.5 / 28.6$ & $22.8 / 11.5$ & $11.5 / 6.5$ & $9.1 / 10.6$ & $2.5: 1.3: 1.0 / 1.1: 0.6: 1.0$ \\
\hline JH3-1/JH3-2 & $40.8 / 20.0$ & $22.0 / 8.2$ & $9.9 / 7.2$ & $8.9 / 4.6$ & $2.5: 1.1: 1.0 / 1.8: 1.6: 1.0$ \\
\hline JH4-1 & 30.9 & 15.6 & 8.6 & 6.7 & $2.3: 1.3: 1.0$ \\
\hline JH5-1/JH5-2 & $40.9 / 59.0$ & $29.8 / 44.0$ & $3.8 / 8.3$ & $7.3 / 6.8$ & $4.1: 0.5: 1.0 / 6.5: 1.2: 1.0$ \\
\hline JH6-1/JH6-2 & $34.3 / 26.9$ & $12.4 / 13.0$ & $8.0 / 6.9$ & $13.9 / 7.0$ & 0.9:0.6:1.0/1.9:1.0:1.0 \\
\hline A1-1/A1-2 & $51.8 / 36.0$ & $41.9 / 31.0$ & $2.4 / 2.8$ & $7.5 / 2.2$ & 5.6:0.3:1.0/14.3:1.3:1.0 \\
\hline $\mathrm{A} 2-1 / \mathrm{A} 2-2$ & $28.5 / 9.4$ & $21.5 / 8.6$ & $3.7 / 0.8$ & 3.2/n.d. & $6.6: 1.2: 1.0 / 11.1: 1.0: 0.0$ \\
\hline A3-1 & 47.9 & 32.9 & 9.3 & 5.7 & $5.7: 1.6: 1.0$ \\
\hline AH1-1 & 16.1 & 14.4 & 1.7 & n.d. ${ }^{* *}$ & $8.3: 1.0: 0.0$ \\
\hline AH2-1 & 35.4 & 31.5 & 1.3 & 2.6 & $12.2: 0.5: 1.0$ \\
\hline АH3-1/AH3-2 & $65.5 / 72.1$ & $39.5 / 33.0$ & $11.4 / 21.9$ & $14.6 / 17.2$ & 2.7:0.8:1.0/1.9:1.3:1.0 \\
\hline AH4-1/AH4-2 & $56.5 / 50.6$ & $40.3 / 29.8$ & $7.4 / 10.2$ & $8.7 / 10.6$ & $4.6: 0.9: 1.0 / 2.8: 1.0: 1.0$ \\
\hline AH5-1/AH5-2 & $50.4 / 47.3$ & $34.6 / 28.0$ & $7.3 / 5.0$ & $8.5 / 14.3$ & $4.1: 0.9: 1.0 / 2.0: 0.4: 1.0$ \\
\hline AH6-1/AH6-2 & $55.9 / 50.4$ & $33.2 / 33.4$ & $6.6 / 7.4$ & $16.0 / 9.7$ & $2.1: 0.4: 1.0 / 3.5: 0.8: 1.0$ \\
\hline AH7-1/AH7-2 & $40.4 / 29.0$ & $21.1 / 18.4$ & $4.8 / 3.5$ & $14.4 / 7.0$ & $1.5: 0.3: 1.0 / 2.6: 0.5: 1.0$ \\
\hline AH8-1/AH8-2 & $17.5 / 15.7$ & $11.0 / 8.8$ & $2.4 / 2.9$ & $4.1 / 3.9$ & $2.7: 0.6: 1.0 / 2.3: 0.7: 1.0$ \\
\hline $\mathrm{T} 1-1 / \mathrm{T} 1-2$ & n.d. & n.d. & n.d. & n.d. & - \\
\hline $\mathrm{T} 2-1 / \mathrm{T} 2-2$ & $9.7^{*} / 6.9^{*}$ & $7.0^{*} / 5.0^{*}$ & $2.6^{*} / 1.9^{*}$ & n.d./n.d. & $2.7: 1.0: 0.0 / 2.7: 1.0: 0.0$ \\
\hline T3-1/T3-2 & n.d. $/ 7.7^{*}$ & n.d. $/ 3.8^{*}$ & n.d. $/ 2.5^{*}$ & n.d. $/ 1.5^{*}$ & - /2.6:1.7:1.0 \\
\hline TH1-1/TH1-2 & $6.5^{*} / 16.1$ & $2.5^{*} / 7.0$ & $0.7^{*} / 3.7$ & $3.3^{*} / 5.4$ & $0.8: 0.2: 1.0 / 1.3: 0.7: 1.0$ \\
\hline $\mathrm{H} 1-1$ & $6.5^{*}$ & $5.9^{*}$ & $0.6^{*}$ & n.d. & $9.1: 1.0: 0.0$ \\
\hline $\mathrm{H} 2-1 / \mathrm{H} 2-2$ & n.d. $/ 8.3^{*}$ & n.d. $/ 3.5^{*}$ & n.d. $/ 1.8^{*}$ & n.d. $/ 2.9^{*}$ & - /1.2:0.6:1.0 \\
\hline H3-1/H3-2 & n.d. & n.d. & n.d. & n.d. & - \\
\hline HR1 & $11.3^{*}$ & $4.9^{*}$ & $2.9^{*}$ & $3.5^{*}$ & $1.4: 0.8: 1.0$ \\
\hline HR2 & $8.4^{*}$ & $4.1^{*}$ & $1.0^{*}$ & $3.3^{*}$ & $1.2: 0.3: 1.0$ \\
\hline HR3 & $5.9^{*}$ & $5.1^{*}$ & $0.8^{*}$ & n.d. & $6.0: 1.0: 0.0$ \\
\hline
\end{tabular}

* just identifiable Aroclor pattern

** n.d.: no Aroclor pattern identified

며, 이들 하천의 상류구간 또한 다른 두 개 하천에 비해 오염원이 적게 분포하고 있다. 이러한 점을 볼 때 과거 지천 주변에서의 산업활동에 따른 오염의 영향이 하천 퇴적물 중 $\mathrm{PCBs}$ 잔류농도에 반영된 것으로 판단된다.

중랑천과 안양천에서 $\mathrm{PCBs}$ 잔류농도가 가장 높은 지 점은 공통적으로 이들 지천과 한강이 합류되는 지점으 로 각각 $\mathrm{JH} 1$ 지점 및 $\mathrm{AH} 3$ 지점이었다. 이들 지점은 중 랑천과 안양천의 하상에서 잔류하였거나 부유물질에 흡 착된 $\mathrm{PCBs}$ 가 한강과 합류되는 지역에서 침전물로 쌓 이면서 지천 상류측에 비해 상대적으로 높은 잔류량을
나타내는 것으로 사료된다. 중랑천과 한강이 합류되는 지점은 하폭이 넓고 본류인 한강이 거의 수직으로 굽 이쳐 흐르는 구조로서 중랑천에서 흘러나오는 수체의 유속저하로 부유물의 침전이 많을 것으로 판단된다. 안 양천의 경우 서해(west sea) 조수의 영향을 많이 받는 지점으로 서해안 만조 시 유량의 정체가 일어나게 되 어 한강과 합류되는 부분에서 장기간에 걸쳐 퇴적물 및 오염물질의 축적이 일어날 수 있다. ${ }^{19)}$ 또한 안양천 합 류부의 퇴적물은 펄(mud)이 다른 지점들에 비해 잘 발 달되어 있어 $\mathrm{PCBs}$ 의 흡착이 더 용이할 것으로 판단된 


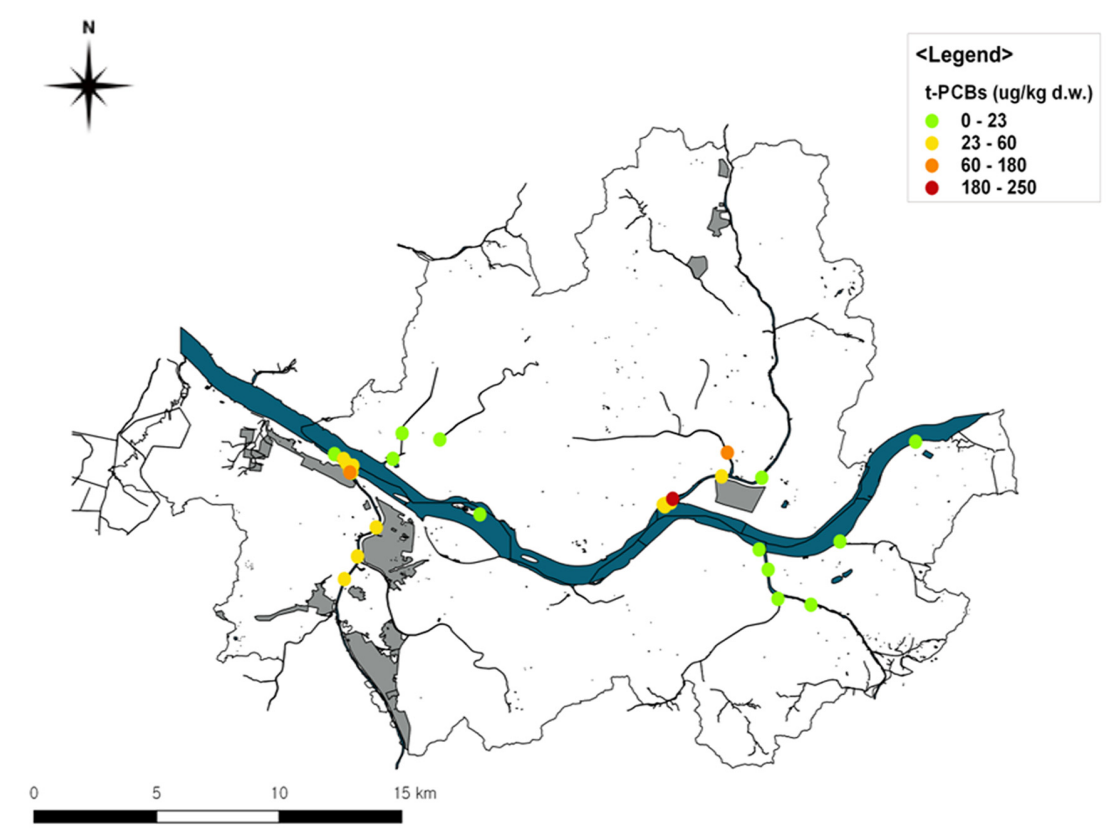

Fig. 2. Status of PCBs remaining in the sediment and location of industrial zone(gray colored area in the figure) in Seoul.

다. 두 지천 모두 합류 이후의 지점에서 퇴적물 중 잔 류 PCBs의 농도는 감소하는 것을 볼 수 있었으며, 중 랑천 합류이후 약 $12 \mathrm{~km}$ 하류의 HR3지점에서는 방법 검출한계 미만의 수준에서 Aroclor의 패턴만 확인할 수 있었다. 본 연구의 4 개 지천들과 합류하기 이전 지점인 한강 상류의 $\mathrm{HR} 1$ 지점 및 $\mathrm{HR} 2$ 지점에서의 $\mathrm{PCBs}$ 농 도도 방법검출한계 미만으로 나타났으나 Aroclor의 흔 적은 확인할 수 있었다.

또한 본 연구에서의 퇴적물 주상시료의 깊이가 $8 \mathrm{~cm} 53 \mathrm{~cm}$ 정도이었고, 대부분 2 개 층으로 분리하여 채 취하였는데, 일부 지점의 퇴적물을 제외하고는 퇴적물 시료의 상층과 하층의 $\mathrm{PCBs}$ 농도의 차이가 심하지 않 는 것으로 나타났다. 두 층간 $\mathrm{PCBs}$ 농도의 상대편차율 (relative percent difference, 이하 RPD)은 J3지점, JH1 지점 그리고 $\mathrm{A} 2$ 지점에서 각각 $163 \%, 107 \%, 101 \%$ 로 높게 나타났고, 나머지 지점들에서의 $\mathrm{RPD}$ 는 평균 $30 \%$ 정도 $(0.5 \%$ 85\%) 수준으로 나타났다. RPD가 $100 \%$ 를 초과하는 세 지점의 경우 모두 모래질의 퇴적물 층이 었는데, 이는 파쇄와 체질을 통해 제조된 전처리용 시 료에 더 많은 양의 분쇄된 모래질이 포함되어 이로 인 한 희석효과가 작용하였을 가능성이 있는 것으로 사료 된다. 일반적으로 퇴적물의 상부 표층에서 검출되는 $\mathrm{PCBs}$ 는 하부 퇴적물에서 검출되는 $\mathrm{PCBs}$ 에 비해 최근 에 유입된 것으로 볼 수 있어 ${ }^{20,21)}$, 하천으로의 새로운
유입이 없다면 상부 퇴적물에서의 PCBs 농도는 하부 퇴적물에 비해 농도가 낮을 것으로 예상할 수 있다. 그 러나 본 연구에서 나타난 결과를 보면 오히려 상부 퇴 적물 중 $\mathrm{PCBs}$ 농도가 하부 퇴적물에 비해 더 높거나 비슷하게 나타난 지점들이 대부분이었다. 우리나라에서 1996년 이래 PCBs의 제조와 사용이 전면적으로 금지 된 것을 고려하면 최근까지 하천으로 $\mathrm{PCBs}$ 가 유입되 고 있다고 생각하기는 어려울 것으로 사료되며, 소각 등 비의도적으로 생성된 $\mathrm{PCBs}$ 의 대기를 통한 유입의 경우도 $\mathrm{GC}$ 크로마토그램에 나타난 Aroclor 피크패턴을 볼 때 가능성은 낮아 보인다. 따라서 본 연구에서 나타 난 퇴적물의 상부와 하부에서의 $\mathrm{PCBs}$ 농도분포는 퇴 적물 내부에서 공극수를 통한 확산이나 $\mathrm{PCBs}$ 를 흡착 하고 있던 입자들의 상부이동 등 퇴적물 내부의 물리 화학적인 현상이 작용한 결과로 판단된다.

한편, $\mathrm{GC}-\mathrm{ECD}$ 를 이용하여 $\mathrm{PCBs}$ 를 분석하게 되면 크로마토그램의 패턴을 이용해서 직관적으로 Aroclor의 종류를 파악할 수 있고, 적절한 동족체를 선정한다면 개별 Aroclor별로 정량을 할 수 있다. 분석결과 퇴적물 에서 검출되는 PCBs는 Aroclor1242, Aroclor1254, Aroclor1260이 혼합되어 있었으며, 가장 많이 존재하는 것은 Aroclor1242로 나타났다. 전 세계적으로 $\mathrm{PCBs}$ 의 주요 사용처는 변압기와 축전기의 절연유로 파악되며, 우리나라의 경우 사용실태가 조사되어 있지 않지만 주 

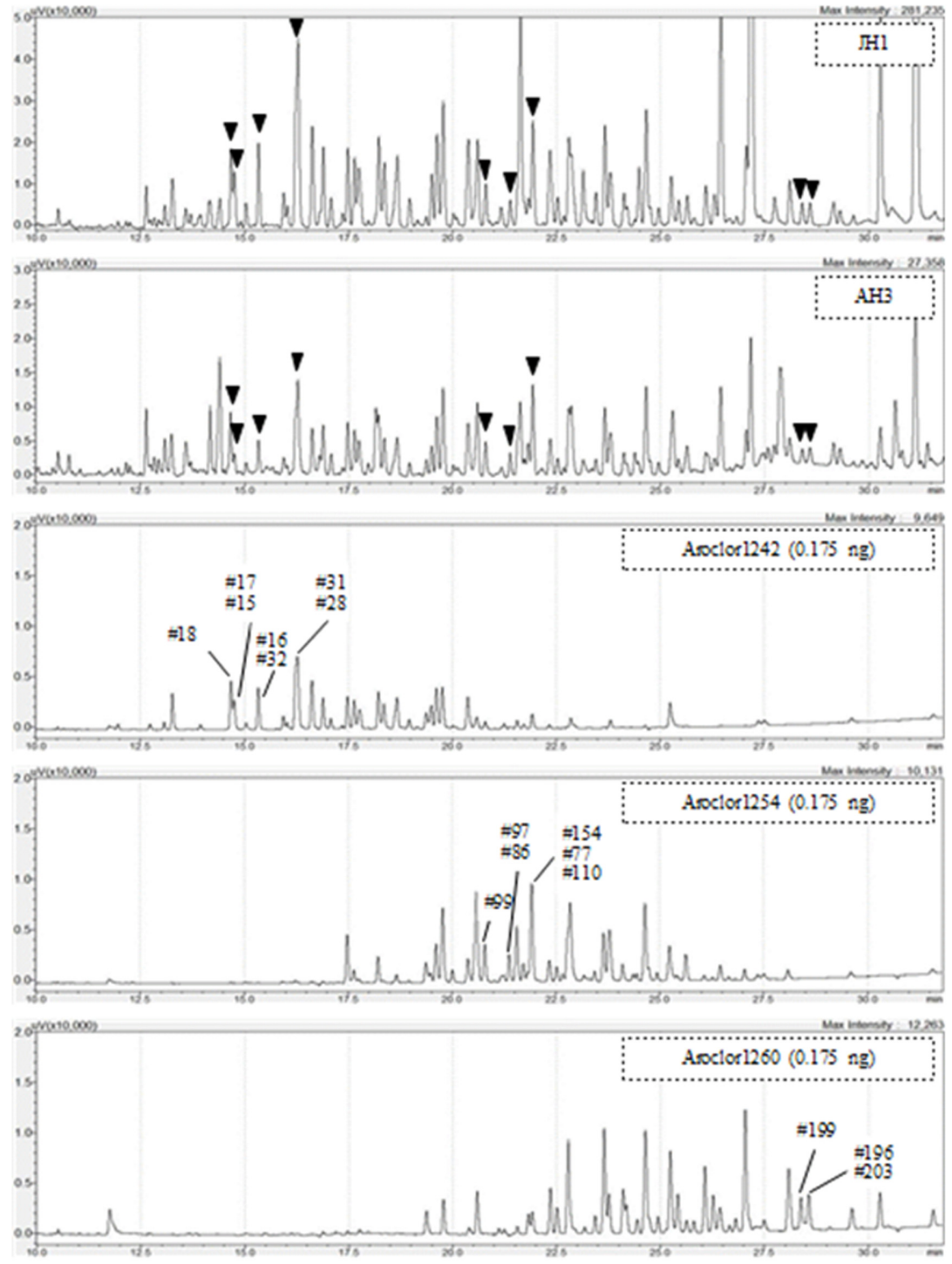

Fig. 3. Chromatogram patterns of Aroclor standards and samples ( $\mathrm{JH} 1$ and $\mathrm{AH} 3$ ).

로 변압기와 축전기 등 전기 기기에서의 사용은 확인 되고 있다. 1960년대 이후 우리나라에서 변압기의 절연 유로 주로 사용된 제품은 Aroclor1242, Aroclor1254, Aroclor1260으로 알려져 있고, 단품 또는 혼합제품으로 사용되어 왔다. ${ }^{22)}$ 본 연구에서도 이들 세 가지 제품의 $\mathrm{PCBs}$ 가 대부분의 시료에서 검출되었고, 피크패턴으로 볼 때 다른 제품의 흔적은 나타나지 않았다.

Fig. 3은 중랑천과 안양천이 한강과 합류하는 지점의 퇴적물 시료에서 검출되는 Aroclor의 $\mathrm{GC}$ 크로마토그램 을 보여주고 있다. 시료에서 나타나는 $\mathrm{GC}$ 크로마토그 램이 각 Aroclor 표준물질의 피크패턴과 매우 흡사하게
일치하는 것으로 볼 수 있는데, 1996년 이후 Aroclor 의 수입과 사용이 금지된 것을 감안하면 오래 전에 환 경 중으로 배출되었던 $\mathrm{PCBs}$ 의 경우에도 분해가 더디 게 진행되어 Aroclor의 패턴이 유지되고 있음을 볼 수 있다. 시료의 크로마토그램에서 나타나는 일부 방해 피 크들은 정제과정에서 제거되지 않은 성분으로 질량분 석기로 확인한 결과 $\mathrm{PCBs}$ 동족체가 아니었고, 정량피 크와도 겹치지 않아 정량상의 문제를 발생시키지는 않 는 것으로 파악되었다. 이러한 결과들로 볼 때 한강 및 지천의 퇴적물에서 검출되는 $\mathrm{PCBs}$ 는 비록 비의도적으 로 배출된 동족체를 미량으로 포함할 수 있겠지만 대 
부분 PCBs 제품에 의한 것으로 판단할 수 있다.

\subsection{Dioxin-like PCBs의 추정}

$\mathrm{PCBs}$ 동족체 중에서 12종은 $\mathrm{dl}-\mathrm{PCB}$ 라고 불리는데 이들은 다이옥신과 유사한 구조를 가지고 독성이 강해 위해성 평가에서 중요한 항목이다. Aroclor 제품에는 $\mathrm{dl}-\mathrm{PCBs}$ 동족체가 함유되어 있는데, 특히 Aroclor1254 에 다량 포함되어 있다. ${ }^{11,23)}$ 따라서 환경시료 중에서도 Aroclor 제품이 검출될 경우 이들 시료에 상당한 양의 $\mathrm{dl}-\mathrm{PCBs}$ 가 함유되었을 것으로 예상할 수 있다. 본 연구 에서 조사된 퇴적물 중 이들 개별 Aroclor의 농도와 선행 논문들에서 제시하는 각각의 Aroclor에 함유된 dl$\mathrm{PCBs}$ 의 함량 정보를 이용해서 퇴적물 중에 함유된 $\mathrm{dl}-$ $\mathrm{PCBs}$ 농도와 $\mathrm{TEQ}$ 를 추정하는 시도를 해 보았다. 이러 한 추정은 실제 $\mathrm{HRMS}$ 를 이용해서 분석한 결과와는 차이가 있을 수 있으나 dl-PCBs를 매우 경제적인 방법 으로 추정할 수 있는 장점이 있다고 판단된다.

서 등 ${ }^{24)}$ 은 한강의 서울시 구간인 광나루와 망원지구 의 퇴적물에서 각각 $0.047 \mu \mathrm{g} / \mathrm{kg}$ d.w. 및 $0.204 \mu \mathrm{g} / \mathrm{kg}$ d.w.의 dl-PCBs가 검출되는 것으로 보고하였다. 서울시 광나루 구간의 정확한 시료채취 위치를 알 수 없지만 본 연구의 HR2지점과 한강을 사이에 두고 맞은 편에 위치한 지점으로 보이며, $\mathrm{HR} 2$ 지점의 $\mathrm{dl}-\mathrm{PCBs}$ 의 추정치 는 $0.24 \mu \mathrm{g} / \mathrm{kg}$ d.w.로 계산되었다. 망원지구의 경우는 본 연구에서 HR3지점과 약 $10 \mathrm{~km}$ 하류에 위치하고 있
으며, HR3지점의 dl-PCBs는 $0.18 \mu \mathrm{g} / \mathrm{kg}$ d.w.으로 추정 되었다. 결과적으로 이 논문에서의 제시된 값들은 검출 된 dl-PCBs 농도가 낮고, 본 연구의 조사지점과 거리 차이가 커 검출되는 $\mathrm{dl}-\mathrm{PCBs}$ 의 농도차이가 크게 나타 나는 것으로 사료된다.

한편 국립환경과학원의 조사 ${ }^{25)}$ 에서는 안양천 합류 후 $4.53 \mu \mathrm{g} / \mathrm{kg}$ d.w., 중랑천 합류 후 $2.02 \mu \mathrm{g} / \mathrm{kg}$ d.w. 그리 고 탄천 합류 후 $0.88 \mu \mathrm{g} / \mathrm{kg}$ d.w.의 dl-PCBs가 퇴적물 에서 검출된 것으로 보고한 바 있으며, 이 조사결과는 이전의 서 등의 연구에 비해 조사지점의 검출되는 농 도수준이 높고 본 연구의 조사지점과 거리 차이가 적 어 두 연구의 결과를 비교하는데 무리가 없을 것으로 판단된다. 비교대상 지점은 국립환경과학원의 과거 보 고에서 탄천 합류 후 지점과 중랑천 합류 지점이었고 이 지점은 본 연구의 $\mathrm{TH} 1$ 및 $\mathrm{JH} 1$ 지점과 대략 $80 \mathrm{~m}$ 및 $800 \mathrm{~m}$ 거리에 위치하고 있다. Fig. 4에서 보는 바 와 같이 서로 다른 분석방법을 적용한 두 조사결과에 서 인접한 지점 간에 잔류하는 농도의 RPD가 각각 $28.6 \%$ 및 $7.7 \%$ 로 나타났다. 이 비교에서도 저농도의 경우가 편차가 다소 큰 것을 볼 수 있으나 퇴적물의 불균질성과 조사의 시차 그리고 비용효과 등의 분석목 적을 고려할 때 본 연구에서 시도한 dl-PCBs 추정방법 은 적용성이 충분할 것으로 판단된다.

Table 6은 본 연구에서 PCBs가 상대적으로 많이 검 출된 두 지천의 퇴적물에서 추정된 $\mathrm{dl}-\mathrm{PCBs}$ 의 잔류농

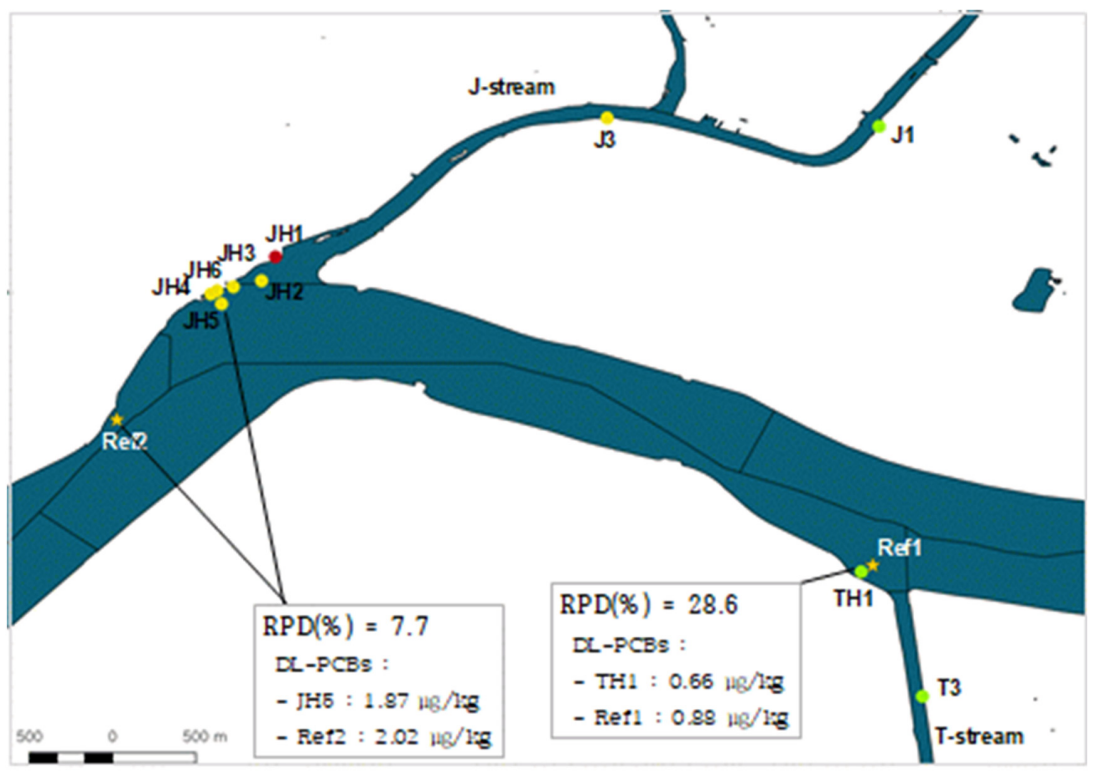

Fig. 4. Comparison of dl-PCB concentration using GC-ECD in this study and GC-HRMS in the reference article. 
Table 6. dl-PCBs $(\mu \mathrm{g} / \mathrm{kg}$ d.w.) and total TEQ (ng-TEQ $/ \mathrm{kg}$ d.w.) in sediments at two tributaries of the Han river

\begin{tabular}{|c|c|c|c|c|c|c|c|}
\hline \multirow{2}{*}{ Sample points } & \multicolumn{3}{|c|}{ J-stream } & \multirow{2}{*}{ Sample points } & \multicolumn{3}{|c|}{ "A-stream } \\
\hline & Total PCBs & dl-PCBs & TEQ & & Total PCBs & dl-PCBs & TEQ \\
\hline $\mathrm{J} 1$ & 15.5 & 0.79 & 0.08 & A1 & 51.8 & 1.08 & 0.19 \\
\hline $\mathrm{J} 2$ & 64.6 & 4.23 & 0.34 & $\mathrm{~A} 2$ & 28.5 & 0.87 & 0.12 \\
\hline $\mathrm{J} 3$ & 35.3 & 1.83 & 0.15 & A3 & 47.9 & 1.80 & 0.21 \\
\hline JH1 & 207.5 & 8.19 & 0.88 & AH1 & 16.1 & 0.45 & 0.07 \\
\hline $\mathrm{JH} 2$ & 43.5 & 1.99 & 0.19 & $\mathrm{AH} 2$ & 35.4 & 0.71 & 0.14 \\
\hline JH3 & 40.8 & 1.76 & 0.17 & $\mathrm{AH} 3$ & 72.1 & 3.61 & 0.31 \\
\hline JH4 & 30.9 & 1.46 & 0.13 & $\mathrm{AH} 4$ & 56.5 & 1.73 & 0.23 \\
\hline JH5 & 59.0 & 1.87 & 0.25 & AH5 & 50.4 & 1.62 & 0.20 \\
\hline \multirow[t]{3}{*}{ JH6 } & 34.3 & 1.44 & 0.12 & AH6 & 55.9 & 1.62 & 0.20 \\
\hline & & & & AH7 & 40.4 & 1.17 & 0.13 \\
\hline & & & & AH8 & 17.5 & 1.17 & 0.07 \\
\hline
\end{tabular}

도를 보여주고 있는데, 중랑천의 경우 $0.79 \mu \mathrm{g} / \mathrm{kg}$ d.w. $\sim 8.19 \mu \mathrm{g} / \mathrm{kg}$ d.w., 안양천에서는 $0.45 \mu \mathrm{g} / \mathrm{kg}$ d.w. $\sim 3.61$ $\mu \mathrm{g} / \mathrm{kg}$ d.w.의 dl-PCBs가 존재할 것으로 추정되었으며, $\mathrm{TEQ}$ 는 각각 $0.08 \mathrm{ng}-\mathrm{TEQ} / \mathrm{kg}$ d.w. $0.88 \mathrm{ng}-\mathrm{TEQ} / \mathrm{kg}$ d.w. 및 $0.07 \mathrm{ng}-\mathrm{TEQ} / \mathrm{kg}$ d.w. $\sim 0.31 \mathrm{ng}-\mathrm{TEQ} / \mathrm{kg}$ d.w.로 계산되었다.

\section{3. 저서생태계의 위해성 고찰}

Fig. 5는 중랑천과 안양천 그리고 두 하천이 한강과
합류하는 지점들에서의 $\mathrm{PCBs}$ 잔류현황을 국외의 퇴적 물 관리기준(SQGs)과 비교해서 나타낸 것이다. 현재 국 내에는 퇴적물에 대한 관리기준이 설정되어 있지 않아 본 연구에서 검출된 퇴적물 중의 $\mathrm{PCBs}$ 농도를 미국 $\mathrm{NOAA}$ 에서 제시하는 SQGs과 비교하였는데, 총 $\mathrm{PCBs}$ 를 기준으로 안양천과 중랑천 퇴적물의 경우 대부분의 지점들이 ERL(effective range low, 이하 ERL)값 이상 으로 검출되는 것으로 나타나고 있다. 특히 중랑천과 한강이 합류되는 지점의 경우 ERM(effective range
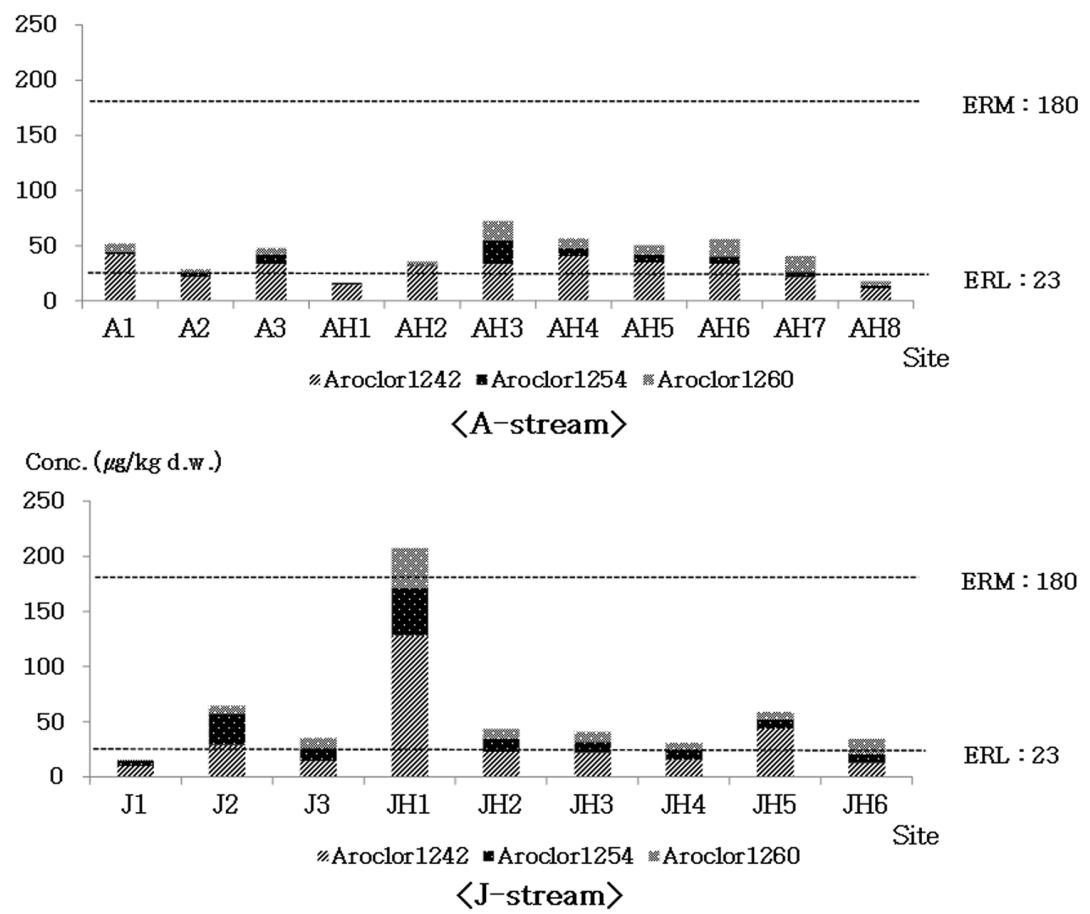

Fig. 5. PCB concentrations in the sediment samples of A-stream and J-stream. 
Table 7. Concentrations of PCBs in the sediments throughout domestic sites

\begin{tabular}{|c|c|c|c|c|}
\hline Author & $\begin{array}{l}\text { Sample site } \\
\text { (No. of site) }\end{array}$ & $\begin{array}{c}\text { Site } \\
\text { characterics }\end{array}$ & $\begin{array}{c}\text { Conc. } \\
\text { ( } \mu g \text { kg d.w.) }\end{array}$ & PCBs type \\
\hline Kim et al.(2012) & Pusan(11) & industrial area & n.d. -76.67 & $\mathrm{t}-\mathrm{PCBs}$ \\
\hline Lee et al.(2002) & Inchon(8) & industrial area & $0.34-9.20$ & $\mathrm{t}-\mathrm{PCBs}$ \\
\hline Kim et al.(2010) & Nakdong river(5) & river & $3.9-60$ & $\mathrm{t}-\mathrm{PCBs}$ \\
\hline Park et al.(2000) & 11 sites in Korea(11) & - & n.d. -0.47 & $\sum 62 \mathrm{PCBs}$ \\
\hline Heo et al.(2016) & Jeju harbor(5) & harbor & $1.62-4.45$ & $\sum 22 \mathrm{PCBs}$ \\
\hline \multirow[t]{4}{*}{ Choi et al.(2011) } & Asan bay(5) & bay & $1.90-3.27$ & $\sum 22 \mathrm{PCBs}$ \\
\hline & $\operatorname{Inchon}(4)$ & industrial area & n.d. & $\mathrm{t}-\mathrm{PCBs}$ \\
\hline & Ulsan(5) & industrial area & $1.0-19.2$ & $\mathrm{t}-\mathrm{PCBs}$ \\
\hline & Masan(6) & industrial area & $2.7-33.5$ & $\mathrm{t}$-PCBs \\
\hline \multirow[t]{4}{*}{ Kim et al.(1996) } & Onsan(3) & industrial area & $4.8-8.2$ & $\mathrm{t}-\mathrm{PCBs}$ \\
\hline & Kwangyang & industrial area & $4.0-60.7$ & $\mathrm{t}-\mathrm{PCBs}$ \\
\hline & Kimpo(4) & industrial area & n.d. - 23.3 & $\mathrm{t}-\mathrm{PCBs}$ \\
\hline & Nakdong(7) & industrial area & $0.19-303$ & $\mathrm{t}-\mathrm{PCBs}$ \\
\hline
\end{tabular}

median, 이하 ERM)값을 초과하는 것으로 나타났다. 이 것은 퇴적물 관리기준을 고려하면 일부 지점의 퇴적물 중 PCBs 농도수준이 저서생물에 악영향을 미칠 가능 성이 있음을 의미한다. 그러나 저서생물의 생태위해성 과 관련한 최근의 연구들 ${ }^{26,27)}$ 은 퇴적물에 존재하는 총 $\mathrm{PCBs}$ 의 농도보다 실제로 오염물질에 대한 생물이용도 (bioavailability)를 생태위해성에 더 중요한 요인으로 파 악하고 있다. 따라서 퇴적물에서 PCBs로 인한 저서생 태계의 위해성을 판단하기 위해서는 퇴적물 중 $\mathrm{PCBs}$ 농도뿐만 아니라 공극수 중의 $\mathrm{PCBs}$ 농도, 퇴적물의 다 양한 물리화학적인 특성들 그리고 접촉시간 등을 고려 하여야 할 것으로 판단된다.

한편 표 7은 국내의 퇴적물을 대상으로 $\mathrm{PCBs}$ 농도 를 조사한 선행 연구들의 결과 ${ }^{28-34)}$ 를 보여주고 있는데, 대부분 부산, 인천, 울산, 마산 등 오염우려가 있는 공 업지역들이 다수 포함되어 있다. 낙동대교 사상공단 남 쪽에서의 PCBs 농도가 $303 \mu \mathrm{g} / \mathrm{kg}$ d.w.로 ERM을 초 과하고 있고, $\mathrm{ERL}$ 을 초과하는 지점들이 일부 나타나기 는 하지만 대부분의 조사결과는 본 연구의 중랑천과 안 양천 및 그 한강 합류부 퇴적물 시료 중 $\mathrm{PCBs}$ 잔류농 도에 비해 상대적으로 낮은 수준으로 검출되고 있는 것 을 볼 수 있다.

본 연구에서 $\mathrm{PCBs}$ 가 주로 검출되었던 두 지천은 서 울시의 소규모로 산재한 공업지역과 인접하여 위치하 고 있으나, 표 7의 조사지점들의 경우 국내 대규모 공 단지역과 인접하는 곳으로 본 연구와는 오염 발생원의 규모 면에서 상당한 차이가 있다. 따라서 본 연구의 퇴 적물에 잔류하는 $\mathrm{PCBs}$ 농도로 볼 때 대규모 공단지역
뿐만 아니라 규모가 작은 도심 공업지역 주변의 중소 하천 퇴적물에 잔류하는 PCBs 현황에 대한 적극적인 조사가 필요할 것으로 판단된다.

\section{4. 결 론}

본 연구에서는 도시하천의 퇴적물 중에 잔류하는 $\mathrm{PCBs}$ 의 농도를 비용효과적인 방법으로 조사하여 보았 다. $\mathrm{GC}-\mathrm{ECD}$ 를 이용해서 퇴적물 중의 $\mathrm{PCBs}$ 를 개별 Aroclor에 특이적인 동족체를 선정하여 각각 정량하였 다. 본 분석법은 인위적으로 사용된 $\mathrm{PCBs}$ 를 정량하는 방법으로서 한정적이며, 비의도적으로 배출된 $\mathrm{PCBs}$ 의 개별 동족체를 정량할 수는 없지만 수계 퇴적물에 주 로 존재하는 Aroclor 등 PCBs 제품의 조사에는 효과 적인 방법이 될 수 있을 것으로 판단된다. 또한 개별 Aroclor의 정량을 통해 dl-PCBs의 추정과 $\mathrm{TEQ}$ 를 간단 한 식을 이용하여 추정할 수 있었다. 비록 동일 시료에 대해 $\mathrm{HRMS}$ 를 이용한 결과와 비교하지는 못했지만, 선 행 연구와 비교를 통해 수용 가능한 결과를 얻을 수 있었다. 퇴적물 중 $\mathrm{PCBs}$ 의 조사는 분석의 난이도와 높 은 비용으로 인해 주로 오염개연성이 큰 대규모 공단 주변의 큰 하천의 퇴적물을 대상이 되는 경우가 많지 만, 본 연구의 방법을 이용하면 상대적으로 용이하게 소규모 하천 퇴적물에 대해 더 많은 조사가 가능할 것 으로 판단된다.

한편, 서울 도심하천 퇴적물 중에 잔류하는 $\mathrm{PCBs}$ 농 도는 공업지역과 인접한 지천에서 상대적으로 높게 나 타났다. 일부 지천의 경우 대부분의 조사지점에서 ERL 
값을 초과하고 있었고, 특정 지점에서는 $\mathrm{ERM}$ 값을 초 과하는 지점도 있었다. 지천 내부에서 상대적으로 농도 가 높은 지점은 한강과 지천의 합류부로 나타났는데, 이 지점들은 하천 수평단면 확대, 흐름의 굴곡 그리고 바다조수의 영향으로 유속이 느려지거나 흐름의 정체 가 일어날 수 있는 지점들이었다. 따라서 하천관리를 위해 퇴적물에 잔류하는 PCBs 등 잔류성 유기오염물 질을 조사하고자 할 때 하천 합류지점은 필수적으로 조 사할 필요가 있는 것으로 판단된다.

\section{참고문헌}

1. 환경부, "PCBs 함유폐기물 적정관리를 위한 폐기물 관 리법 개정사항 검토 연구”, 2006.

2. S. Safe, "Polychlorinated-biphenyls (PCBs) - mutagenicity and carcinogenicity", Mutation Research/Reviews in Genetic Toxicology, 1989, 220, 31-47.

3. Washington state department of ecology, "PCBs in sediments at Selected Sites in Puget Sound", February 2002.

4. T. Combi, S. Miserocchi, L. Langone, and R. Guerra, "Polychlorinated biphenyls (PCBs) in sediments from the western Adriatic Sea: sources, historical trends and inventories", Science of The Total Environment, 2016, $562,580-587$.

5. 환경부, "POPs 제품·폐기물 실태조사 및 관리방안 마 련 연구(II)", 2005.

6. H. Arfaeinia, Z. Asadgol, E. Ahmadi, M. Seifi, M. Moradi, and S. Dobaradaran, "Characteristics, distribution and sources of polychlorinated biphenyls (PCBs) in coastal sediments from the heavily industrialized area of Asalouyeh, Iran", Water Science \& Technology, 2017, 76, 3340-3350.

7. K. Pozo, R. Urrutia, M. Mariottini, A. Rudolph, J. Banguera, K. Pozo, O. Parra, and S. Focardi, "Levels of Persistent Organic Pollutants (POPs) in sediments from Lenga estuary, central Chile", Marine Pollution Bulletin, 2014, 79, 338-341.

8. G. Kruitwagen, H. B. Pratap, A. Covaci, and S. E. W. Bonga, "Status of mangrove ecosystems along the coast of Tanzania", Marine Pollution Bulletin, 2008, 56, 1022-1042.

9. J. E. Baker, P. D. Capel, and S. J. Eisenreich, "Influence of colloids in sediment/water partition coefficients of polychlorobiphenyls congeners in natural waters", Environmental Science \& Technology, 1986, 20, 1136-1143.

10. J. Baker, S. Eisenreich, T. Johnson, and B. Halfman, "Chlorinated hydrocarbon cycling in the benthic nepheloid layer of Lake Superior", Environmental Science \&
Technology, 1985, 19, 854-861.

11. D. R. Rushneck, A. Beliveaub, B. Fowler, C. Hamilton, D. Hoover, K. Kaye, M. Berg, T. Smith, William A. Telliard, H. Roman, E. Ruder, and L. Ryan, "Concentration of dioxin-like PCB congener in unweathered Aroclors by HRGC/HRMS using EPA Method 1668A", Chemosphere, 2004, 54, 79-87.

12. 국립환경과학원, “수질오염공정시험기준(ES 04504.1b)", 2018.

13. 국립환경과학원, “폐기물공정시험기준(ES 06502.1a)”, 2017.

14. 국립환경과학원, “토양오염공정시험기준(ES 07554.1b)", 2018.

15. P. Ssebugere, B. T. Kiremire, B. Henkelmann, S. Bernhöft, J. Wasswa, G. N. Kasozi, and K. W. Schramm, "PCDD/Fs and dioxin-like PCBs in surface sediments from Lake Victoria, East Africa", Science of the Total Environment, 2013, 528-533.

16. A. C. Souza, S. Taniguchi, R. C. L. Figueira, R. C. Montone, M. C. Bícego, and C. C. Martins, "Historical records and spatial distribution of high hazard PCBs levels in sediments around a large South American industrial coastal area (Santos Estuary, Brazil)", Journal of Hazardous Materials, 2018, 428-435.

17. W. Wang, J. Bai, G. Zhang, J. Jia, X. Wang, X. Liu, and B. Cui, "Occurrence, sources and ecotoxicological risks of polychlorinated biphenyls (PCBs) in sediment cores from urban, rural and reclamation-affected rivers of the Pearl River Delta, China”, Chemosphere, 2019, 218, 359-367.

18. 신창호, “서울 준공업지역의 산업경쟁력 강화방안", 서 울도시연구, 2009, 10, 27-44.

19. 송창근, 김형준, 이동섭, “감조하천에서 조위 및 유량조 건에 따른 역류분색”, 한국안전학회지, 2014, 29, 104-110.

20. C. Dias-Ferreira, R. L. Pato, J. B. Varejão, A. O. Tavares, and A. J. D. Ferreira, "Heavy metal and PCB spatial distribution pattern in sediments within an urban catchment-contribution of historical pollution sources", Journal of Soils and Sediments, 2016, 16, 2594-2605.

21. Q. Zhao, J. Bai, Q. Lu, Z. Gao, J. Jia, B. Cui, and X. Liu, "Polychlorinated biphenyls (PCBs) in sediments/soils of different wetlands along 100-year coastal reclamation chronosequence in the Pearl River Estuary, China", Environmental Pollution, 2016, 213, 860-869.

22. 신선경, 김혜진, 정다위, 김진경, 김경심, 정영희, 정일 록, “폴리염화비페닐류 함유 폐기물의 적정관리방안에 관한 연구”, 국립환경과학원, 2003.

23. 국립환경연구원, "주요 배출원별 Coplanar PCBs의 발 생기전 및 배출특성에 관한 연구(I)”, 2004, 52-53. 
24. 서용찬, 이석현, 김경심, 송병주, 김종국, "한강 수계 중 coplanar-PCBs의 잔류 농도 및 거동 특성 연구”, 대한환경공학회지, 2004, 26, 1225-1231.

25. 국립환경과학원, "하천 퇴적물 중 POPs 축적도 모니터 링사업(1)”, 2006, 90-94.

26. J. J. Ortega-Calvo, J. Harmsen, J. R. Parsons, K. T. Semple, M. D. Aitken, C. Ajao, C. Eadsforth, M. GalayBurgos, R. Naidu, R. Oliver, W. J. G. M. Peijnenburg, J. Römbke, G. Streck, and B. Versonnen, "From Bioavailability Science to Regulation of Organic Chemicals", Environmental Science \& Technology, 2015, 49, 10255-10264.

27. F. Portet-Koltalo, T. Gardes, M. Debret, Y. Copard, S. Marcotte, C. Morin, and Q. Laperdrix, "Bioaccessibility of polycyclic aromatic compounds (PAHs, PCBs) and trace elements: Influencing factors and determination in a river sediment core", Journal of Hazardous Materials, 2020, 384, 121499.
28. 김현승, 김일규, "도심하천유역의 $\mathrm{PCBs}$ 농도 분포", 한국상하수도학회지, 2012, 26, 757-766.

29. 이동훈, 김교근, "인천연안 퇴적물 중 $\mathrm{PCB}$ 의 분포", 한국분석과학회지, 2002, 15, 287-299.

30. 김영호, 오정근, 김종국, 김경수, "하천 퇴적물 중 $\mathrm{PCBs}$ 농도분포 및 발생원 해석”, 대한환경공학회지, 2010, 32, 995-1000.

31. 박현미, 류재천, 김영만, 이강봉, “국내의 다양한 장소 에서 채취된 수질, 토양 및 저질시료의 폴리염화비페닐 에 의한 오염도”, 한국분석과학회지, 2000, 13, 802-809.

32. 허륜용, 김상규, 조은일, "제주항내 퇴적물의 $\mathrm{PCBs}$ 분 포특성”, 해양환경안전학회지, 2016, 22, 220-227.

33. 최진영, 이성규, 방재현, 양동범, 홍기훈, 신경훈, “아산 만해역 어류체내와 퇴적물중의 $\mathrm{PCB}$ 와 유기염소계농약 분포”, 한국해양과학기술원, 2011, 33, 45-53.

34. 김기환, 이윤, "국내 연안 퇴적물내 $\mathrm{PCBs}(\mathrm{Polychlorinated}$ Biphenyls) 오염도 현황”, 대한환경위생공학회지, 1996, $11,9-12$. 